\title{
Inhibitory Effect of Bryophyllum pinnatum (Lam.) Oken leaf Extract and their Fractions on a-amylase, a-glucosidase and Cholinesterase Enzyme
}

\author{
Oluwafemi Adeleke Ojo ${ }^{1 *}$, Adebola Busola Ojo², Basiru Olaitan Ajiboye ${ }^{1}$, Oluranti Olaiya ${ }^{2}$, Ayodeji Akawa ${ }^{2}$, \\ Oyindamola Olaoye ${ }^{1}$, Omosola Olufisayo Anifowose ${ }^{3}$, Olajumoke Idowu ${ }^{4}$, Oluwaseun Olasehinde ${ }^{2}$, \\ Tajudeen Obafemi ${ }^{1}$, Joseph Awe' ${ }^{1}$, Babatunji Emmanuel Oyinloye ${ }^{1}$
}

\section{Oluwafemi Adeleke Ojo 1*, Adebola Busola Ojo², Basiru Olaitan Ajiboye', Oluranti Olaiya ${ }^{2}$, Ayodeji Akawa ${ }^{2}$, Oyindamola Olaoye ${ }^{1}$, Omosola Olufisayo Anifowose ${ }^{3}$, Olajumoke Idowu ${ }^{4}$, Oluwaseun Olasehinde ${ }^{2}$, Tajudeen Obafemi', Joseph Awe', Babatunji Emmanuel Oyinloye ${ }^{1}$}

'Department of Biochemistry, Afe Babalola University, Ado-Ekiti, Ekiti State, NIGERIA.

${ }^{2}$ Department of Medical Biochemistry, Afe Babalola University, Ado-Ekiti, Ekiti State, NIGERIA.

${ }^{3}$ Department of Physiology, Afe Babalola University, Ado-Ekiti, Ekiti State, NIGERIA.

${ }^{4}$ Department of Chemistry, Afe Babalola University, Ado-Ekiti, Ekiti State, NIGERIA.

\section{Correspondence}

Oluwafemi Adeleke Ojo

Department of Biochemistry, Afe Babalola University, Ado-Ekiti, NIGERIA.

Phone no : 234-703-782-4647

E-mail: oluwafemiadeleke08@gmail.com

\section{History}

- Submission Date: 16-11-2017;

- Review completed: 08-12-2017;

- Accepted Date: 08-12-2017

DOI : 10.5530/pj.2018.3.82

Article Available online

http://www.phcogj.com/v10/i3

Copyright

(c) 2018 Phcog.Net. This is an openaccess article distributed under the terms of the Creative Commons Attribution 4.0 International license.

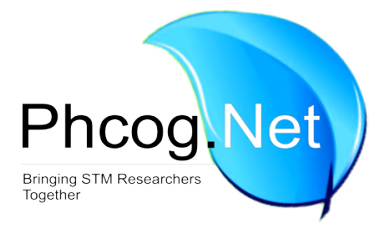

\begin{abstract}
Bryophyllum pinnatum (Lam.) Oken leaves are employed as food and as traditional medicines. This study investigates the antioxidant activity (reducing power, DPPH, ABTS, FRAP, $\mathrm{H}_{2} \mathrm{O}$ scavenging ability and metal ion chelating), carbohydrate digesting enzymes activity and inhibitory activity of cholinergic enzyme of aqueous extract and fractions (n-hexane, ethyl acetate, n-butanol, residual aqueous fraction) of $B$. pinnatum leaves were investigated. Results showed that aqueous extract of $B$. pinnatum exhibited DPPH radical scavenging abilities, iron chelation, hydrogen peroxide scavenging abilities and reducing power $\left(\mathrm{Fe}^{3+}-\mathrm{Fe}^{2+}\right)$. B. pinnatum aqueous extract also had considerably $\alpha$-amylase and $\alpha$-glucosidase inhibitory activities with $I C_{50}$ values $149.20 \pm 14.44 \mu \mathrm{g} / \mathrm{mL}$ and $126.15 \pm 9.76 \mu \mathrm{g} / \mathrm{mL}$ respectively. Our findings indicated that ethyl acetate fraction contained a considerably higher $(p<0.05)$ amount of total phenolic, flavonoids, total antioxidant, FRAP, metal ion, ABTS and DPPH radical scavenging activity than other solvent fractions. Furthermore, the ethyl acetate fraction elicited a significantly higher $(p<0.05)$ inhibitory effects on $\boldsymbol{\alpha}$-glucosidase $\left(I C_{50}=70.90 \pm 1.23 \mu \mathrm{g} / \mathrm{ml}\right), \alpha$-amylase $\left(I C_{50}=62.45\right.$ $\pm 1.22 \mu \mathrm{g} / \mathrm{ml})$, acetylcholinesterase (AChE) $\left(I C_{50}=66.75 \mu \mathrm{g} / \mathrm{mL}\right.$ ) and butyrylcholinesterase (BChE) $\left(I C_{50}=62.97 \mu \mathrm{g} / \mathrm{mL}\right.$ ) activities than other fractions. Hence, B. pinnatum leaves were rich in biologically active components; thus, could be employed to formulate new plant-based pharmaceutical and nutraceutical drugs to improve human health.

Key words: Bryophyllum pinnatum (Lam.), Oken, Antioxidants, Enzyme inhibitory activity,
\end{abstract} Cholinesterase.

\section{INTRODUCTION}

With the emerging trends in science, the therapeutic properties of plants have got importance role everywhere, attributable to its pharmacologic activities (such as free radical scavengers, anti-ulcer, anti-malarial, anti-cancer, anti-inflammatory, anti-microbial) and nutraceuticals properties. ${ }^{1}$ Reports have targeted on beneficial roles of phytochemicals from plants as well as their health-promoting effects. Amid the numerous secondary metabolites with biological activities, phenolics are accountable for the aforesaid biochemical properties. ${ }^{2}$ World societies progressively involved on well-being and diet, natural plant products are budding as valuable alternatives aimed at replacing synthetic drugs. On the premise of the aforesaid issues, new plant-based products or Phytomedicine remain thought of as potential resources.
Several native plants are utilized in folklore (traditional) medicine nowadays to treat illnesses and cure wounds. ${ }^{3}$ One among such therapeutic plants includes Bryophyllum Pinnatum (Lam.) Oken. The medicinal importance of plants paved means for the in depth pharmaceutical production of drugs from its synthetic chemical, utilizing the active ingredients of that particular plant origin. ${ }^{4}$ Bryophyllum Pinnatum (Lam.) Oken (Crassulaceae) Synonyms: Kalanchoe pinnata (Lam.) Pers. Usually referred to as life leaf and air plant is widely cultivated as a garden ornamental in tropical America, China, India, Australia and tropical Africa. The plant flourishes throughout the Southern part of Nigeria. Bryophyllum Pinnatum (Lam.) Oken, a succulent recurrent herb that cultivates in tropical, subtropical and warm temperate climate zone. It is employed in ethno medicine as a curative plant for the treatment of high blood pressure. ${ }^{5}$ Literatures searches reported Bryophyllum
Cite this article: Ojo OA, Ojo AB, Ajiboye BO, Olaiya O, Akawa A, Olaoye O, Anifowose OO, Idowu O, Olasehinde O, Obafemi T, Awe J, Oyinloye BE. Inhibitory effect of Bryophyllum pinnatum (Lam.) Oken leaf extract and their fractions on a-amylase, a-glucosidase and cholinesterase enzyme. Pharmacog J. 2018;10(3):497-506. 
juice extract as helpful for the cure of kidney stones. ${ }^{6}$ Although, there's no proof based clinical indication for these uses in modern medicine and so, such usage might prove dangerous and even fatal in some cases. The leaves of the plant have great medicinal value and are used both internally as well as externally. It additionally possesses numerous properties like haemostatic, refrigerant, emollient, mucilaginous, vulnerary, antiinflammatory, ${ }^{5}$ disinfectant and tonic. The herb has been used to facilitate the induction of placental delivery in newly born babies within the southern part of Nigeria. The plant additionally encompasses hydrogen cyanide (HCN), Oxalic acid, citric acid, isocitric acid, oxaloacetate and succinic acid. It's also contains a variety of vitamins such as vitamin $\mathrm{C}$, vitamin $B_{2}$, vitamin $B_{1}$ vitamin $B_{3}$ vitamin $B_{6}$, Cysteine, Casein hydrolysate and amino acids such as glutamic acid, methionine and phenylalanine.? The herb may be a suitable supply of inorganic elements such as $\mathrm{Na}, \mathrm{Ca}$, $\mathrm{K}, \mathrm{P}, \mathrm{Mg}, \mathrm{Mn}, \mathrm{Fe}, \mathrm{Cu}, \mathrm{Zn}$ (3). The Bufadienolides which are active components of Bryophyllum Pinnatum possess anti tumorous, ${ }^{8}$ antibacterial, ${ }^{9}$ and insecticidal actions. Although, some literatures have reported Bufadienolides to be toxic and as like cardiac glycosides toxicity.

Edible fruits, herbs and vegetables largely contain high levels of polyphenols that have high antioxidant activity and are useful against stress conditions in the human body, hence presenting vital health benefits. Though, not solely edible plants are beneficial from this point of view, however, additionally non-edible plant materials are mostly examined with this purpose. ${ }^{10,11,12}$ In this sense, several food supplements and pharmaceutical products have been developed in recent years exploiting plant-derived constituents. Therefore, the biochemical composition of plants ordinarily employed in folk medicines, or from the same species, are being considered to look for new alternatives in the food industry. The main objective of the study here presented was to analyze the antioxidant capacity (free radical scavenging assays, reducing power, metal chelating and DPPH, ABTS assays), and enzyme inhibitory activity (cholinesterases, $\alpha$-amylase and a-glucosidase) of Bryophyllum Pinnatum (Lam.) Oken leaves from which scarce data is obtainable in the scientific

\section{MATERIALS AND METHODS}

\section{Chemicals}

All reagents and standards were of analytical reagent (AR) grade unless stated otherwise. Folin-Ciocalteu's reagent and methanol were purchased from Merck (Darmstadt, Germany). 2,2-Diphenyl-1-picrylhydrazyl (DPPH), ABTS radical cation (2,2'-azino-bis(3-ethylbenzothiazoline)6-sulphonic acid), DTNB (5,5-dithio-bis(2- nitrobenzoic) acid), trolox, EDTA, acarbose, AChE (acetylcholinesterase; Electric ell acetylcholinesterase, Type-VI-S, EC 3.1.1.7), BChE (butyrylcholinesterase; horse serum butyrylcholinesterase, EC 3.1.1.8), acetylthiocholine iodide (ATCI), butyrylthiocholine chloride (BTCl), a-amylase (from porcine pancreas, EC 3.2.1.1) and a-glucosidase (from Saccharomyces cerevisiae, EC 3.2.1.20) were purchased from Sigma Chemical Co. (Sigma-Aldrich $\mathrm{GmbH}$, Sternheim, Germany). All other chemicals and solvents were of analytical grade.

\section{Plant material and extraction procedure}

Fresh leaves of Bryophyllum pinnatum (Lam.) Oken was obtained (January, 2017) at Oja Oba market Ado-Ekiti. Fresh leaves of Bryophyllum pinnatum was identified and documented by a senior plant scientist from the Department of Plant Biology, University of Ilorin, Nigeria and a voucher specimen number was deposited appropriately at the University herbarium. All plant names in this manuscript are arranged according to the modern revision in "The Plant List", and correspond to the good practices in publishing studies on herbal plants, as described by. ${ }^{13}$ The fresh leaves were air-dried for three weeks and ground to powder using a mechanical blender. To obtain aqueous extracts, $500 \mathrm{~g}$ of air-dried leaves were soaked with $2000 \mathrm{~mL}$ of water for $48 \mathrm{~h} .{ }^{14}$ Aqueous extracts obtained were lyophilized and stored until use.

\section{Solvent partitioned fractionation of crude aqueous extracts}

Aqueous leaves extract of $B$. pinnatum was $(50 \mathrm{~g})$ sequentially extracted with solvents of increasing polarity (hexane, ethyl acetate, n-butanol and water). Aqueous extract was partitioned between n-hexane $(2 \times 200 \mathrm{~mL})$ and water to obtain $n$-hexane fraction (HF) and aqueous portion. The aqueous portion obtained was further partitioned by ethyl acetate $(2 \mathrm{x}$ $200 \mathrm{~mL}$ ) to obtain ethyl acetate fraction (EAF) and aqueous portion. The aqueous portion obtained was further partitioned by $n$-butanol $(2 \times 200$ $\mathrm{mL})$ to obtain n-butanol fraction (BF) and residual aqueous fractions (AF). The yield of the aqueous extract was $25.25 \mathrm{~g}$ while the yield for $\mathrm{n}$-hexane fraction, ethyl acetate fraction, $\mathrm{n}$-butanol fraction and residual aqueous fractions are $3.26 \mathrm{~g}, 7.74 \mathrm{~g}, 4.5 \mathrm{~g}$ and $5.5 \mathrm{~g}$ respectively.

\section{Evaluation of Antioxidant Activities of Aqueous and Fractions of $B$. pinnatum leaves Determination of Reducing Property}

The reducing power of the $B$. pinnatum leaf aqueous extract and fractions (HF, EAF, BF, AF) was studied by evaluating the capability of the extract or fractions to scale back $\mathrm{FeCl}_{3}$ solution using the method of..$^{15} 2.5 \mathrm{~mL}$ of extract was mixed with $2.5 \mathrm{~mL}$ of $200 \mathrm{mM}$ phosphate buffer ( $\mathrm{pH} 6.6$ ) and $2.5 \mathrm{~mL}$ of $1 \%$ potassium ferricyanide. Solution was incubated for $20 \mathrm{~min}$ at $50{ }^{\circ} \mathrm{C}$ in a water bath and $2.5 \mathrm{~mL}$ of $10 \%$ trichloroacetic acid was added. Resulting solution was then centrifuged for $10 \mathrm{~min}$ at $650 \mathrm{~g}$. After that, $5 \mathrm{~mL}$ of the filtrate was mixed with an equal volume of water and one $\mathrm{mL}, 0.1 \% \mathrm{FeCl}_{3}$. Above-stated process was conjointly applied to a standard ascorbic acid solution, and absorbance was read at $700 \mathrm{~nm}$. The reducing ability was calculated as percentage inhibition.

\section{Iron $\left(\mathrm{Fe}^{2+}\right)$ chelation assay}

Metal chelating ability of $B$. pinnatum leaf aqueous extract and fractions (HF, EAF, BF, AF) was determined by employing a changed procedure by. ${ }^{16}$ Newly made $500 \mu \mathrm{mol} \mathrm{L}^{-1} \mathrm{FeSO}_{4}(150 \mu \mathrm{L})$ was added to the solution comprising $168 \mu \mathrm{L}$ of $0.1 \mathrm{~mol} \mathrm{~L}^{-1}$ Tris- $\mathrm{HCl}$ ( $\mathrm{pH} 7.4$ ), $218 \mu \mathrm{L}$ saline and the aqueous extract $(20-100 \mu \mathrm{L})$ and fractions. The solution was incubated for $5 \mathrm{~min}$, with addition of $13 \mu \mathrm{L}$ of $0.25 \%$ (w/v) of 1,10 -phenanthroline. Absorbance was read at $510 \mathrm{~nm}$. (EDTA was used as a standard for evaluating metal chelating activity (EDTAE)).

\section{Evaluation of DPPH Free Radical Scavenging Ability}

DPPH scavenging ability of $B$. pinnatum leaf aqueous extract and fractions (HF, EAF, BF, AF) against DPPH free radical was assessed as delineated by ${ }^{17}$ Concisely, suitable dilution of the extract and fractions $(1 \mathrm{~mL})$ was mixed with $1 \mathrm{~mL} 0.4 \mathrm{mM}$ DPPH solution in methanol. The mixture was left within the dark for $30 \mathrm{~min}$ and absorbance was read at $516 \mathrm{~nm}$. DPPH radical scavenging assay was afterwards calculated with reverence to the control (Vitamin C was used as a standard for evaluating DPPH activity).

\section{Estimation of 2, 2-Azino-bis3-ethylbenthiazoline-6sulphonic acid (ABTS.) radical scavenging ability}

2, 2-Azino-bis3-ethylbenthiazoline-6sulphonic acid scavenging ability of $B$. pinnatum leaf aqueous extract and fractions (HF, EAF, BF, AF) was assessed primarily based to the protocol delineated by. ${ }^{18}$ The ABTS was produced by reacting $7 \mathrm{mM}$ ABTS aqueous solution with $\mathrm{K}_{2} \mathrm{~S}_{2} \mathrm{O}_{8}(2.45$ $\mathrm{mM}$, final concentration) within the dark for $16 \mathrm{~h}$ and altering the absorbance at $734 \mathrm{~nm}$ to 0.700 with alcohol. Afterward, $200 \mu \mathrm{L}$ of suitable dilution of extracts and fractions were added to $2.0 \mathrm{~mL}$ ABTS. Solution. Absorbance were read at $734 \mathrm{~nm}$ after $15 \mathrm{~min}$. 


\section{Estimation of Hydrogen peroxide radical scavenging ability}

The capability of the B. pinnatum leaf aqueous extract and fractions (HF, EAF, BF, AF) to scavenge hydrogen peroxide was determined according to the protocol of. ${ }^{19}$ Hydrogen peroxide $(40 \mathrm{mM})$ was prepared in phosphate buffer ( $\mathrm{pH} 7.4)$. Extracts and fractions dissolved $(20-100 \mu \mathrm{g} / \mathrm{mL})$ in distilled water were mixed with hydrogen peroxide solution $(0.6 \mathrm{~mL}$, $40 \mathrm{mM}$ ). Hydrogen peroxide absorbance was determined 10 min later against a solution containing the phosphate buffer without $\mathrm{H}_{2} \mathrm{O}_{2}$ and read at $230 \mathrm{~nm}$. Hydrogen peroxide scavenging powered of both B. pinnatum extracts and fractions were calculated:

$$
\% \text { Scavenged }\left[\mathrm{H}_{2} \mathrm{O}_{2}\right]=\frac{(\text { Abs control }- \text { Abs sample })}{\text { Abs sample }} \times 100
$$

Where Abs control $_{\text {is the absorbance of the control and Abs sample }}$ is the absorbance in the presence of the sample of $B$. pinnatum extracts or fractions.

Quantitative Determination of Total Phenolics, Total Flavonoids, Tannins and vitamin C Quantitative Determination of Total phenolics, total Flavonoids, Tannins and Vitamin. Secondary metabolites and vitamins were quantitatively determined using previously described methods. ${ }^{15,16,18}$

\section{Evaluation of a-amylase inhibitory activity}

Alpha-amylase activity was determined concurring to the protocol delineated by. ${ }^{20} \mathrm{~A}$ volume of $250 \mu \mathrm{L}$ of $\mathrm{B}$. pinnatum leaf aqueous extract and fractions (HF, EAF, BF, AF) at totally different concentrations (20-100 $\left.\mu \mathrm{g} \mathrm{mL}^{-1}\right)$ was incubated with $500 \mu \mathrm{L}$ of porcine pancreatic amylase $(2 \mathrm{U}$ $\mathrm{mL}^{-1}$ ) in $100 \mathrm{mmol} \mathrm{L}^{-1}$ phosphate buffer ( $\mathrm{pH} \mathrm{6.8)}$ at $37^{\circ} \mathrm{C}$ for $20 \mathrm{~min}$. Two hundred and fifty $\mu \mathrm{L}$ of $1 \%$ starch dissolved in $100 \mathrm{mmol} \mathrm{L}^{-1}$ phosphate buffer ( $\mathrm{pH}$ 6.8) was then added to the mixture and incubated at $37^{\circ} \mathrm{C}$ for $1 \mathrm{~h}$. One $\mathrm{mL}$ of DNS color was then added to the solution and boiled for $10 \mathrm{~min}$. The absorbance of resulting mixture was read at $540 \mathrm{~nm}$ and the enzyme inhibitory activity was calculated as percentage of control sample without inhibitors. All assays were applied in triplicate.

$$
\alpha-\text { amylase inhibition }(\%)=\frac{\mathrm{A}_{540} \text { control }-\mathrm{A}_{540} \text { sample }}{\mathrm{A}_{540} \mathrm{control}} \times 100
$$

\section{Estimation of a-glucosidase inhibitory activity}

Alpha-glucosidase inhibitory activity was assessed in line with the protocol delineated by. ${ }^{21}$ with small modifications. Briefly, $250 \mu \mathrm{L}$ of B. pinnatum leaf aqueous extract and fractions (HF, EAF, BF, AF), at different concentrations $\left(20-100 \mu \mathrm{g} \mathrm{mL}^{-1}\right)$, was mixed with $500 \mu \mathrm{L}$ of $1.0 \mathrm{U} \mathrm{mL}^{-1} \alpha$-glucosidase solution in $100 \mathrm{mmol} \mathrm{L}^{-1}$ phosphate buffer (pH 6.8) at $37^{\circ} \mathrm{C}$ for $15 \mathrm{~min}$. Thereafter, $250 \mu \mathrm{L}$ of $\mathrm{pNPG}$ solution (5 mmolL ${ }^{-1}$ ) in $100 \mathrm{mmol} \mathrm{L}^{-1}$ phosphate buffer ( $\mathrm{pH} \mathrm{6.8)} \mathrm{was} \mathrm{added} \mathrm{and}$ therefore the solution was more mixed at $37^{\circ} \mathrm{C}$ for $20 \mathrm{~min}$. The absorbance of the free $p$-nitrophenol was read at $405 \mathrm{~nm}$ and therefore the inhibitory activity was expressed as percentage of a control sample without inhibitors.

$$
\alpha-\text { glucosidase inhibition }(\%)=\frac{\mathrm{A}_{405} \operatorname{control}-\mathrm{A}_{405} \text { sample }}{\mathrm{A}_{405} \mathrm{control}} \times 100
$$

\section{Determination of Cholinesterase Activity}

Estimation of Acetylcholinesterase (AChE) and butyrylcholinesterase inhibitory activity

Inhibitory activity of AChE was evaluated via an adapted colorimetric method as delineated by. ${ }^{22}$ The AChE activity was assessed in a mixture containing $200 \mu \mathrm{L}$ of a solution of AChE $(0.415 \mathrm{U} / \mathrm{mL}$ in $0.1 \mathrm{M}$ phosphate buffer, $\mathrm{pH} 8.0$ ), $100 \mu \mathrm{L}$ of a solution of 5,50-dithiobis (2-nitrobenzoic) acid (DTNB) (3.3mM in $0.1 \mathrm{M}$ phosphate-buffered solution, $\mathrm{pH}$ 7.0) containing $\mathrm{NaHCO}_{3}(6 \mathrm{mM})$, B. pinnatum leaf aqueous extract and fractions (HF, EAF, BF, AF), and $500 \mu \mathrm{L}$ of 4 phosphate buffer of $\mathrm{pH}$ 8.0. After incubation for $20 \mathrm{~min}$ at $25^{\circ} \mathrm{C}, 100 \mu \mathrm{L}$ of $0.05 \mathrm{mM}$ acetylthiocholine iodide solution was added as the substrate, and AChE activity was assessed as change in absorbance reading at $412 \mathrm{~nm}$ for $3 \mathrm{~min}$ at $25^{\circ} \mathrm{C}$ using a spectrophotometer. Also, inhibition of $\mathrm{BChE}$ was evaluated by an adjusted colorimetric method as delineated by. ${ }^{22}$ The BChE activity was assessed in a mixture comprising $200 \mu \mathrm{L}$ of a solution of BChE (0.415 U/mL in $0.1 \mathrm{M}$ phosphate buffer, $\mathrm{pH} 8.0), 100 \mu \mathrm{L}$ solution of 5, 50-dithiobis (2-nitrobenzoic) acid (DTNB) (3.3mM in $0.1 \mathrm{M}$ phosphate-buffered solution, $\mathrm{pH}$ 7.0) containing $\mathrm{NaHCO}_{3}(6 \mathrm{mM})$, B. pinnatum leaf aqueous extract and fractions (HF, EAF, BF, AF), and $500 \mu \mathrm{L}$ of 4 phosphate buffer, $\mathrm{pH}$ 8.0. After incubation for $20 \mathrm{~min}$ at $25^{\circ} \mathrm{C}, 100 \mu \mathrm{L}$ of $0.05 \mathrm{mM}$ butyrylthiocholine iodide solution was added as substrate, and BChE activity was estimated as change in absorbance reading at $412 \mathrm{~nm}$ for $3 \mathrm{~min}$ at $25^{\circ} \mathrm{C}$ using a spectrophotometer. AChE and BChE inhibitory activities were calculated as percentage inhibition (\%).

\section{Data analysis}

Results were expressed as the mean \pm SEM. ${ }^{23}$ The level of significance for the analyses was set to $p<0.05$. Mean values were analyzed and compared using One way analysis of variance and Student's t test. These analyses were performed using the free software $\mathrm{R}$ version $3.1 .1 .^{24}$

\section{RESULTS}

Table 1 shows the results of the total phenolics, total flavonoids, and Vitamin $\mathrm{C}$ content, reducing power and trolox antioxidant capacity by aqueous and various fractions of crude aqueous extract of Bryophyllum pinnatum leaves. The result revealed that both the aqueous and all fractions showed an ability to donate electrons to convert $\mathrm{Fe}^{3+}$ into $\mathrm{Fe}^{2+}$ as indicated by the values presented. Ethyl acetate fraction of Bryophyllum pinnatum leaves $(3499.08 \pm 45.28 \mathrm{mg} \mathrm{AAE} / 100 \mathrm{~g})$ had considerably $(p<0.05)$ higher reducing ability than aqueous extract $(838.77 \pm 39.93 \mathrm{mg} \mathrm{AAE} / 100 \mathrm{~g})$, n-hexane $(338.23 \pm 2.47 \mathrm{mg} \mathrm{AAE} / 100 \mathrm{~g})$, residual aqueous (556.04 \pm $55.89 \mathrm{mg} \mathrm{AAE} / 100 \mathrm{~g})$ and n-butanol $(627.25 \pm 10.39 \mathrm{mg}$ AAE/100g) fractions as presented in Table 1 . As revealed by the results, ethyl acetate fraction of Bryophyllum pinnatum (1049.48 $\pm 26.87 \mathrm{mg} \mathrm{AAE} / 100 \mathrm{~g}) \mathrm{had}$ appreciably $(p<0.05)$ higher antioxidant capacity (Table 1$)$ than aqueous extract (558.08 $\pm 18.96 \mathrm{mg} \mathrm{AAE} / 100 \mathrm{~g})$, residual aqueous (420.24 \pm 40.04 mg AAE/100g), n-butanol (327.47 $\pm 15.28 \mathrm{mg} \mathrm{AAE} / 100 \mathrm{~g})$ and n-hexane (115.86 $\pm 15.28 \mathrm{mg} \mathrm{AAE} / 100 \mathrm{~g})$ fractions.

DPPH radical scavenging ability is displayed in Figure 1, with its $\mathrm{IC}_{50}$ values $(93.64 \pm 3.42 \mu \mathrm{g} / \mathrm{mL})$. The result revealed that the aqueous extracts of Bryophyllum pinnatum scavenged free radicals $(20-100 \mu \mathrm{g} / \mathrm{ml})$.

Figure 2 shows the metal ion chelating ability of aqueous extract of $B$. pinnatum leaves. The result revealed that the aqueous extract of B. pinnatum $\mathrm{IC}_{50}(224.17 \pm 15.22 \mu \mathrm{g} / \mathrm{mL})$ had a high $(p<0.05)$ metal chelating ability.

Figure 3 presents the hydrogen peroxide $\left(\mathrm{H}_{2} \mathrm{O}_{2}\right)$ scavenging activities of aqueous extracts of $B$. pinnatum leaves. The extract was found to exhibit NO inhibition activity. As revealed by the results, the aqueous extract of the leaves possessed $\mathrm{IC}_{50}$ values of $(316.88 \pm 12.75 \mu \mathrm{g} / \mathrm{mL})$.

The radical scavenging ability of the $B$. pinnatum leaves extract was consequently evaluated using the reasonably steady ABTS radical and displayed in Figure 4 with $\mathrm{IC}_{50}(94.97 \pm 3.33 \mu \mathrm{g} / \mathrm{ml})$ value. The results showed that the $B$. pinnatum leaves extract quenched ABTS radical $(20-100 \mu \mathrm{g} / \mathrm{ml})$. 
Table 1: Total phenolic, Flavonoids, Tannins, Vitamin C, reducing power (FRAP) and Trolox equivalent antioxidant capacity (TEAC) by aqueous and various fractions of crude aqueous extract of Bryophyllum pinnatum Leaves.

\begin{tabular}{|c|c|c|c|c|c|c|}
\hline Fractions & $\begin{array}{l}\text { Total Phenolic (mg } \\
\text { GAE/100g) }\end{array}$ & $\begin{array}{c}\text { Total Flavonoid } \\
(\mathrm{mgQE} / 100 \mathrm{~g})\end{array}$ & $\begin{array}{l}\text { Total Tannin } \\
(\mathrm{mgQE} / 100 \mathrm{~g})\end{array}$ & Vitamin $C(\mu \mathrm{g} / \mathrm{g})$ & FRAP (mg AAE/100g) & TEAC (mg AAE/100g) \\
\hline Aqueous & $747.78 \pm 23.07^{a}$ & $442.50 \pm 19.91^{\mathrm{a}}$ & $235.69 \pm 13.14^{\mathrm{a}}$ & $268.54 \pm 14.67^{a}$ & $838.77 \pm 39.93^{a}$ & $558.08 \pm 18.96^{\mathrm{a}}$ \\
\hline n-Hexane & $59.28 \pm 4.47^{\mathrm{d}}$ & - & $55.50 \pm 2.07^{\mathrm{d}}$ & $34.95 \pm 1.02^{\mathrm{d}}$ & $338.23 \pm 2.47^{\mathrm{d}}$ & $115.86 \pm 15.28^{\mathrm{d}}$ \\
\hline Ethyl acetate & $582.46 \pm 21.25^{\mathrm{b}}$ & $397.12 \pm 15.46^{\mathrm{b}}$ & $655.50 \pm 1.21^{\mathrm{b}}$ & $734.95 \pm 1.05^{\mathrm{b}}$ & $3499.08 \pm 45.28^{b}$ & $1049.48 \pm 26.87^{\mathrm{b}}$ \\
\hline n-Butanol & $472.48 \pm 94.06^{c}$ & $247.50 \pm 90.91^{c}$ & $355.50 \pm 10.29^{c}$ & $434.95 \pm 9.05^{c}$ & $627.25 \pm 10.39^{c}$ & $327.47 \pm 15.28^{c}$ \\
\hline Residual aqueous & $465.64 \pm 95.39^{c}$ & $170.00 \pm 52.02^{\mathrm{d}}$ & $204.33 \pm 8.78^{\mathrm{e}}$ & $229.34 \pm 7.21^{\mathrm{e}}$ & $556.04 \pm 55.89^{d}$ & $420.24 \pm 40.04^{c}$ \\
\hline
\end{tabular}

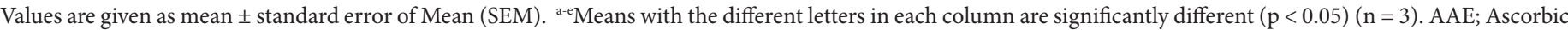
acid equivalents

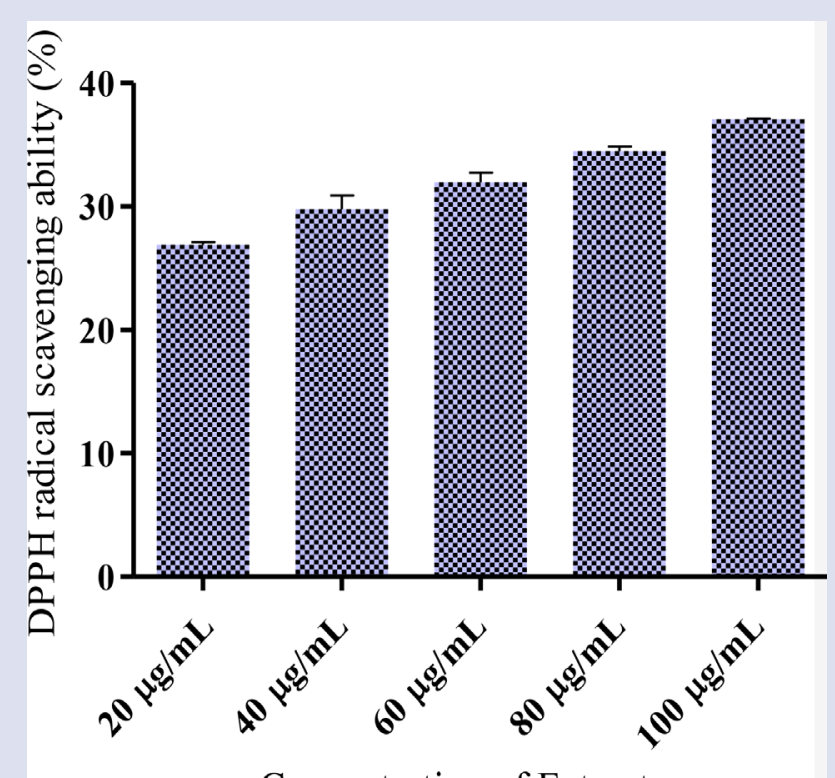

Concentration of Extract

Figure 1:2, 2-diphenyl-1-picrylhydrazyl free radical scavenging ability of aqueous extracts of Bryophyllum pinnatum leaves.

Figure 5 shows the percentage inhibitory activity of $\alpha$ - glucosidase by aqueous extract of $B$. pinnatum leaves. The aqueous extract inhibited $\alpha$-glucosidase in vitro. The concentration of the extract required to cause $50 \%$ inhibition $\left(\mathrm{IC}_{50}\right.$ ) against $\alpha$ - glucosidase was $149.20 \pm 14.44 \mu \mathrm{g} / \mathrm{mL}$.

Figure 6 shows the percentage inhibitory activity of $\alpha$ - amylase by aqueous extract of $B$. pinnatum leaves. Extract had appreciable in vitro inhibitory activity against $\alpha$ - amylase. The $\mathrm{IC}_{50}$ values for the aqueous extract against $\alpha$ - amylase activity was determined from a dose-response curve to be $126.15 \pm 9.76 \mu \mathrm{g} / \mathrm{mL}$.

Figure 7 shows the DPPH radical scavenging activities of the various fractions of $B$. pinnatum leaves. All the fractions showed an ability to quench DPPH free radicals as indicated by the concentration-dependent increase in the percentage inhibition. The ethyl acetate fraction had a consistently higher DPPH radical scavenging activity, as shown by the $\mathrm{IC}_{50}(80.37 \pm 1.54 \mu \mathrm{g} / \mathrm{mL})$ than residual aqueous $(98.33 \pm 4.65 \mu \mathrm{g} / \mathrm{mL})$, n-butanol $(87.35 \pm 2.11 \mu \mathrm{g} / \mathrm{mL})$ and $\mathrm{n}$-hexane $(175.49 \pm 15.73 \mu \mathrm{g} / \mathrm{mL})$ fractions.

Metal ion chelating ability of various fractions of B. pinnatum is presented in Figure 8 . The result revealed that the ethyl acetate fractions of $B$. pinnatum $(79.82 \pm 1.08 \mu \mathrm{g} / \mathrm{mL})$ had a considerably $(p<0.05)$ higher

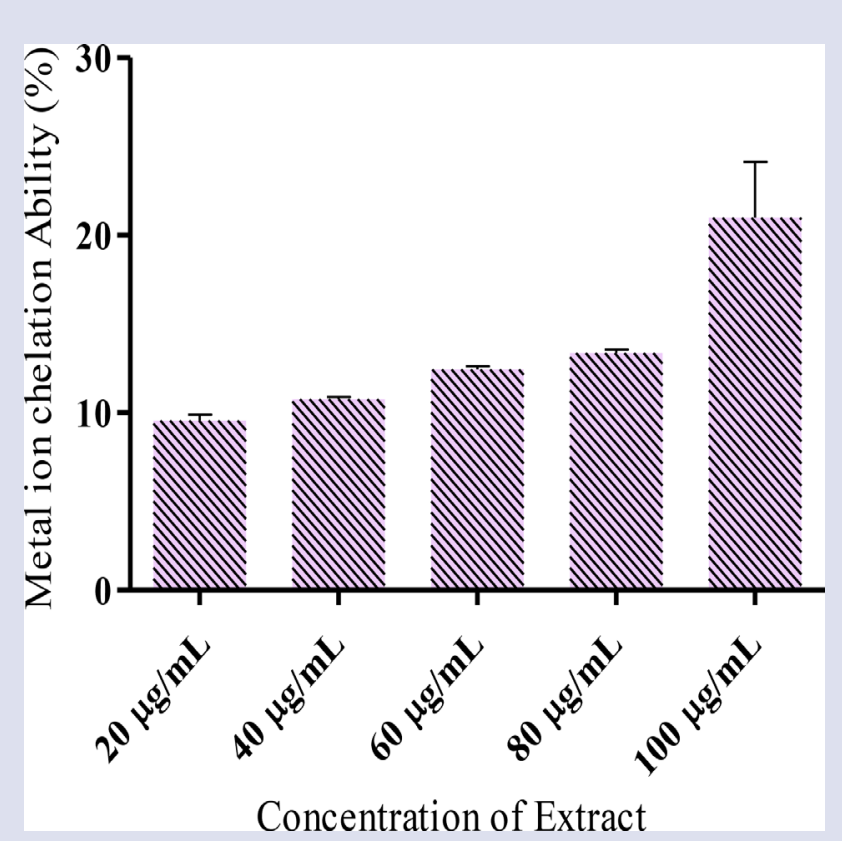

Figure 2: Metal ion chelating ability of aqueous extracts of Bryophyllum pinnatum leaves.

metal chelating properties than residual aqueous $(103.81 \pm 12.45 \mu \mathrm{g} / \mathrm{mL})$, n-hexane $(100.99 \pm 17.50 \mu \mathrm{g} / \mathrm{mL})$ and $\mathrm{n}$-butanol $(118.46 \pm 14.76 \mu \mathrm{g} / \mathrm{mL})$ fractions.

Figure 9 shows the $\mathrm{H}_{2} \mathrm{O}_{2}$ radical scavenging activities of the various fractions of $B$. pinnatum. A concentration-dependent $\mathrm{H}_{2} \mathrm{O}_{2}$ inhibition activities were observed for ethyl acetate fraction which was significantly higher $(128.79 \pm 19.02 \mu \mathrm{g} / \mathrm{mL})(p<0.05)$ than the results of residual aqueous $(749.88 \pm 45.98 \mu \mathrm{g} / \mathrm{mL}), \mathrm{n}$-hexane $(549.62 \pm 21.02 \mu \mathrm{g} / \mathrm{mL})$ and n-butanol $(170.03 \pm 9.12 \mu \mathrm{g} / \mathrm{mL})$ fractions as indicated by their $\mathrm{IC}_{50}$ values. The free radical scavenging ability of the various fractions of $B$. pinnatum leaves was consequently evaluated using the abstemiously steady ABTS radical and displayed in Figure 10. Results showed that ethyl acetate fraction of $B$. pinnatum leaves $(66.82 \pm 1.02 \mu \mathrm{g} / \mathrm{mL})$ quenched ABTS radical $(20-100 \mu \mathrm{g} / \mathrm{ml})$ better than residual aqueous $(96.65 \pm 4.78 \mu \mathrm{g} / \mathrm{mL})$, n-hexane $(393.72 \pm 23.02 \mu \mathrm{g} / \mathrm{mL})$ and n-butanol $(103.09 \pm 10.12 \mu \mathrm{g} / \mathrm{mL})$ fractions as indicated by their $\mathrm{IC}_{50}$ values.

Figure 11 shows the percentage inhibition of $\alpha$ - glucosidase by various fractions of crude aqueous extract $B$. pinnatum leaves. The fractions inhibited $\alpha$-glucosidase activities in vitro. More polar fractions demonstrated appreciably higher $(p<0.05)$ a-glucosidase activity than less 


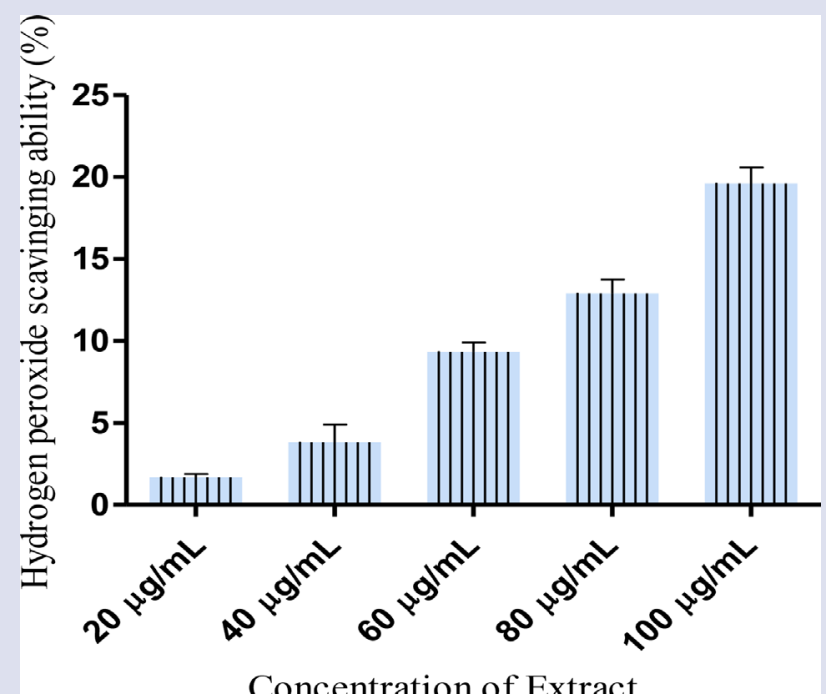

Figure 3: Hydrogen peroxide scavenging ability of aqueous extracts of Bryophyllum pinnatum leaves.

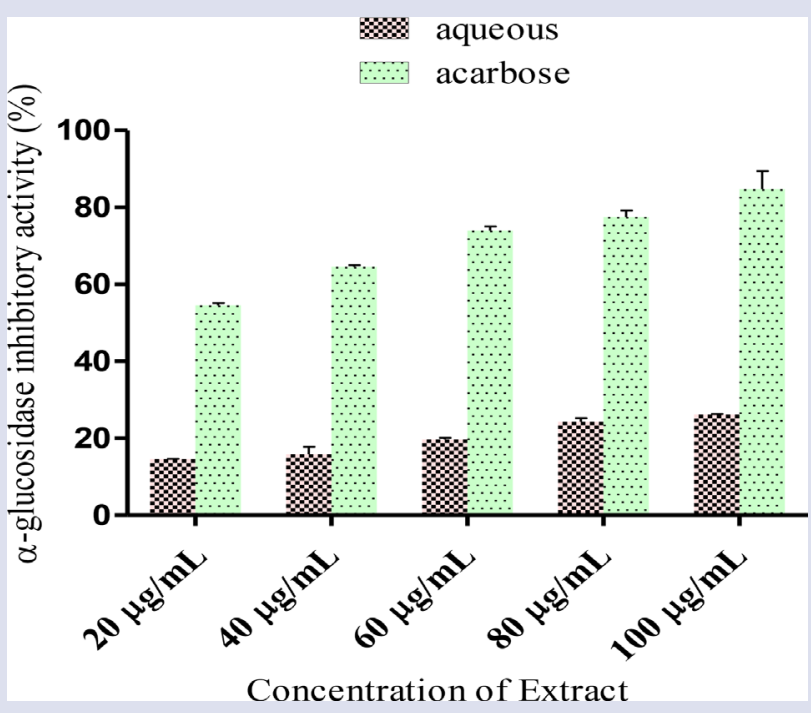

Figure 5: a-glucosidase inhibitory activities of aqueous extract of Bryophyllum pinnatum Leaves.

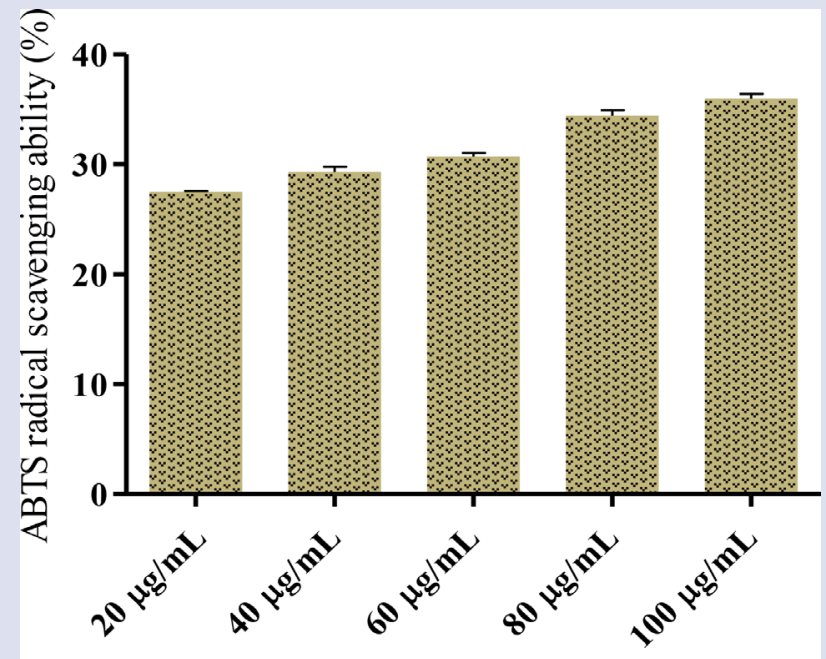

Concentration of Extract

Figure 4: ABTS scavenging ability of aqueous extracts of Bryophyllum pinnatum leaves. polar fractions. However, within the more polar fractions, the inhibitory activity demonstrated by the ethyl acetate fraction $(70.90 \pm 1.23 \mu \mathrm{g} / \mathrm{mL})$ was considerably higher $(p<0.05)$ than residual aqueous $(173.85 \pm 14.69$ $\mu \mathrm{g} / \mathrm{mL}), \mathrm{n}$-hexane $(419.71 \pm 26.52 \mu \mathrm{g} / \mathrm{mL})$ and $\mathrm{n}$-butanol $(83.05 \pm 3.12$ $\mu \mathrm{g} / \mathrm{mL}$ ) fractions as indicated by their $\mathrm{IC}_{50}$ values.

Figure 12 shows the percentage inhibition of $\alpha$ - amylase by various fraction of crude aqueous extract of $B$. pinnatum leaves. The fractions had appreciable in vitro inhibitory activity against $\alpha$ - amylase in a fashion with ethyl acetate fraction $(62.45 \pm 1.22 \mu \mathrm{g} / \mathrm{mL})$ showing a considerably higher $(p<0.05) \alpha$-amylase activity than n-butanol $(104.78 \pm 9.54 \mu \mathrm{g} / \mathrm{mL})$, residual aqueous $(139.07 \pm 12.53 \mu \mathrm{g} / \mathrm{mL})$ and $n$-hexane $(695.82 \pm 46.12$ $\mu \mathrm{g} / \mathrm{mL}$ ) fractions.

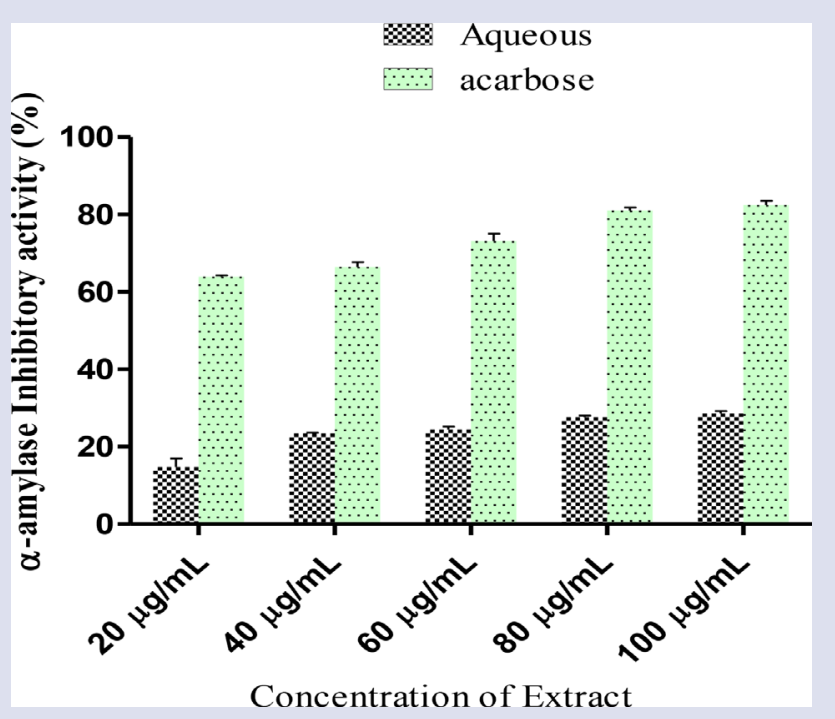

Figure 6: a-amylase inhibitory activities of aqueous extract of Bryophyllum pinnatum Leaves.
Acetylcholinesterase inhibitory properties of B. pinnatum leaf aqueous extract and fractions was examined and displayed in Figure 13; the result shown the ethyl acetate fraction inhibiting AChE activity in a concentration-dependent manner $(20-100 \mu \mathrm{g} / \mathrm{mL})$, having an $\mathrm{IC}_{50}$ (extract concentration causing $50 \%$ inhibition) value $=66.75 \mu \mathrm{g} / \mathrm{mL}$ better than both the aqueous $99.05 \mu \mathrm{g} / \mathrm{mL}$ and n-hexane $(197.42 \mu \mathrm{g} / \mathrm{mL})$, n-butanol $(99.41 \mu \mathrm{g} / \mathrm{mL})$ and residual aqueous fractions $(122.91 \mu \mathrm{g} / \mathrm{mL})$. Likewise, the ability of $B$. pinnatum leaf aqueous extract and fractions to inhibit butyrylcholinesterase activity was also assessed, and the result is displayed in Figure 14. This revealed that the ethyl acetate fraction inhibited $\mathrm{BChE}$ as the concentration increases $(20-100 \mu \mathrm{g} / \mathrm{mL})$ having an $\mathrm{IC}_{50}$ (extract concentration causing $50 \%$ inhibition) value $=62.97 \mu \mathrm{g} / \mathrm{mL}$. 


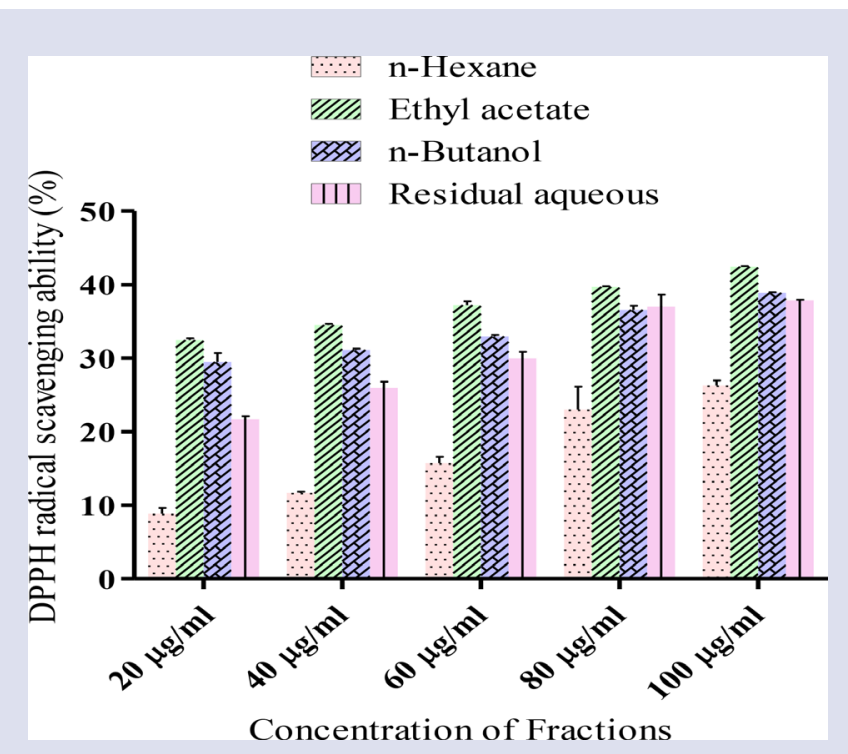

Figure 7: DPPH scavenging ability of various fractions from crude aqueous extracts of Bryophyllum pinnatum leaves.

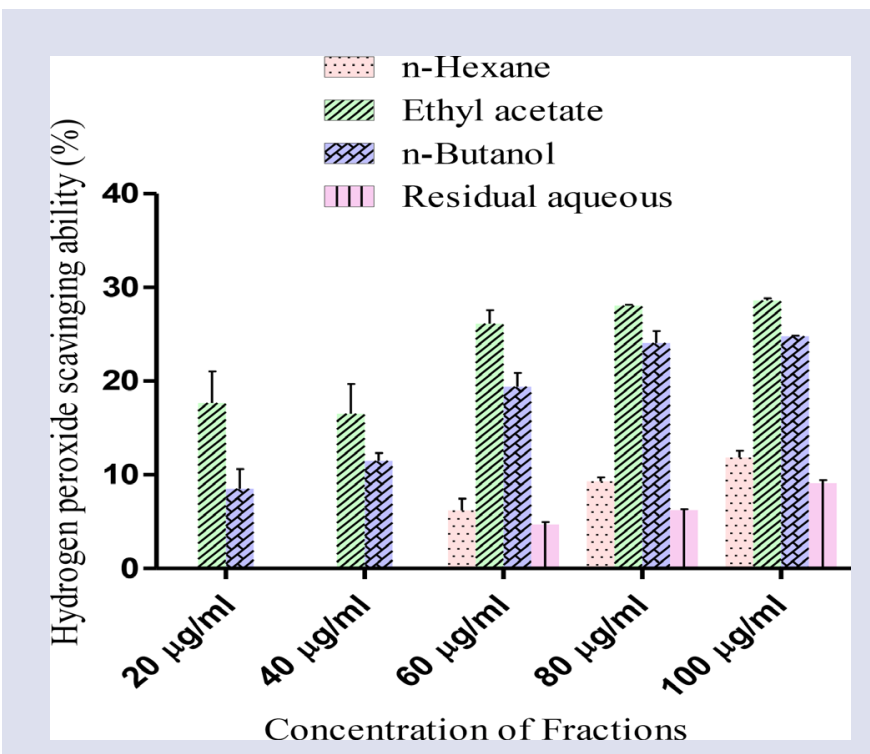

Figure 9: Hydrogen peroxide scavenging ability of various fractions from crude aqueous extracts of Bryophyllum pinnatum leaves.

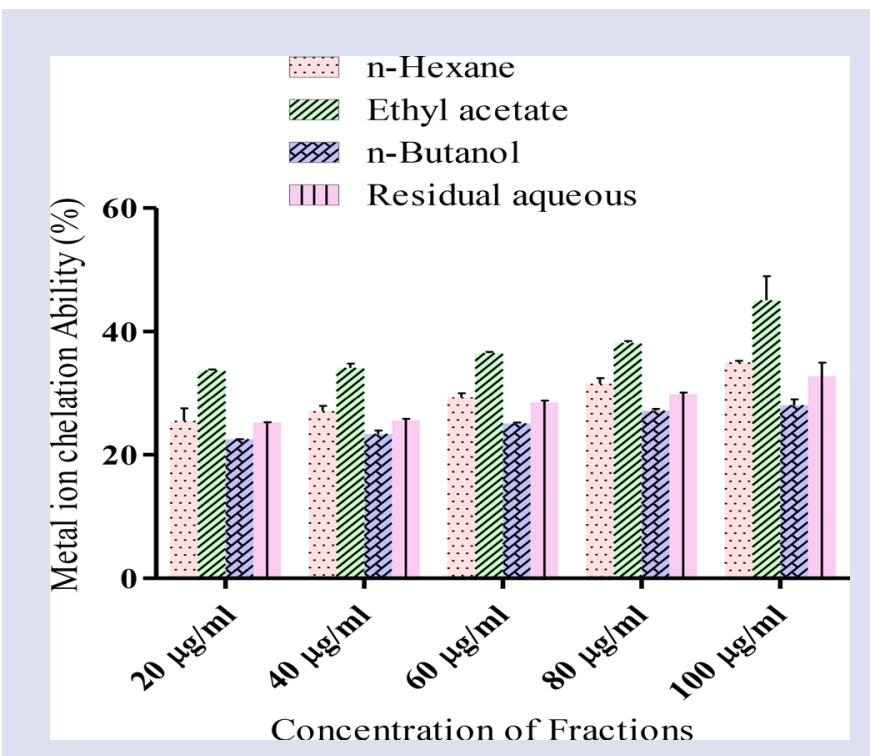

Figure 8: Metal ion chelating ability of various fractions from crude aqueous extracts of Bryophyllum pinnatum leaves.
Moreover, aqueous extracts of $B$. pinnatum inhibited both acetylcholinesterase (AChE) and butyrylcholinesterase (BChE). The result revealed that the aqueous extracts and various fractions (n-hexane, ethyl acetate, n-butanol and residual aqueous) inhibited $\mathrm{AChE}$ and $\mathrm{BChE}$ activities.

\section{DISCUSSION}

This work investigated the antioxidant activities and enzyme inhibitory properties of aqueous extract and fractions of Bryophyllum pinnatum leaf. Recently, phenolic compounds have attracted great interest for their potential use in the development of new nutraceuticals or pharmaceuticals due to their remarkable antioxidant, anti-inflammatory, anticancer or antibacterial activities. Hence, several of the possible protecting effects of polyphenols could rely upon their concentration because of high doses

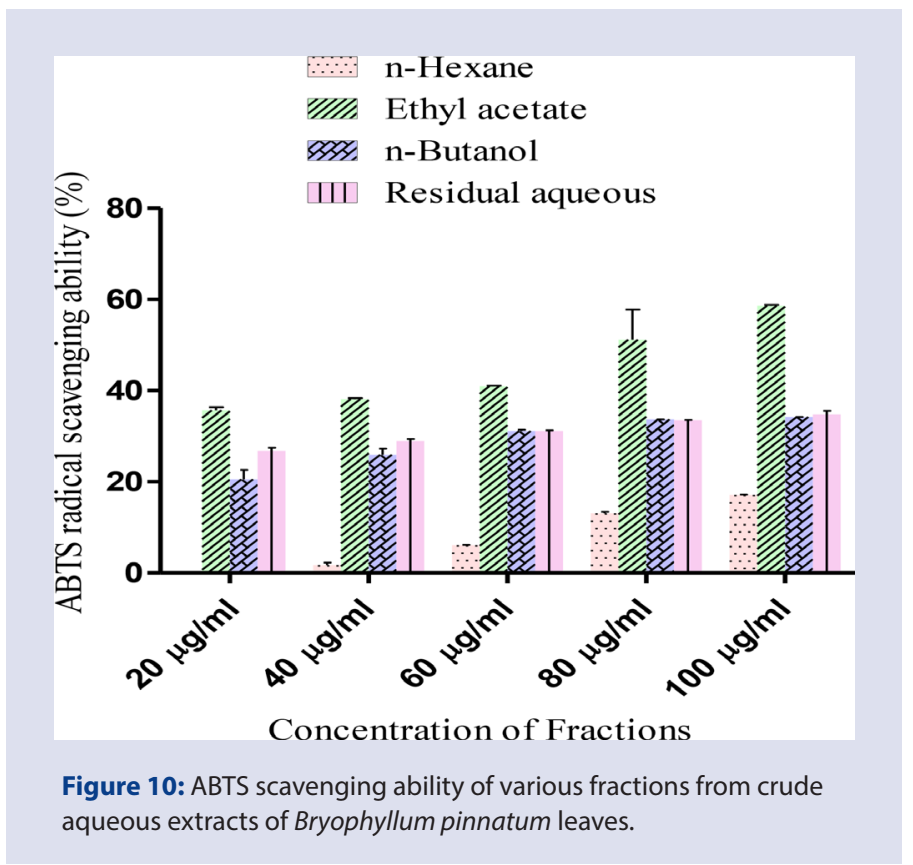

of some of these compounds which is also a pro-oxidant and negatively have an effect on cell growth causing toxicity. ${ }^{25}$ This might result to a multifaceted mechanism that comprises as a minimum an antioxidantpro-oxidant consequence of the polyphenolic compounds. Several present antioxidants show mutagenic and genotoxic responses in cells reflecting its oxidant activity. ${ }^{25,26}$ Flavonoids are major classes of phenolics and many studies have documented their biological and pharmacological activities. ${ }^{27,28,29}$ Though, the phenolic contents of $B$. pinnatum aqueous extracts and various fractions were determined respectively. Ethyl acetate fraction of $B$. pinnatum had higher total phenolic and flavonoid content $(582.46 \pm 21.25 \mathrm{mg} \mathrm{GAE} / \mathrm{g}$ and $397.12 \pm 15.46 \mathrm{mg} \mathrm{RE} / \mathrm{g})$ than aqueous extract and all other fractions. The reducing powers of the aqueous extracts and various fractions of $B$. pinnatum was evaluated supported 


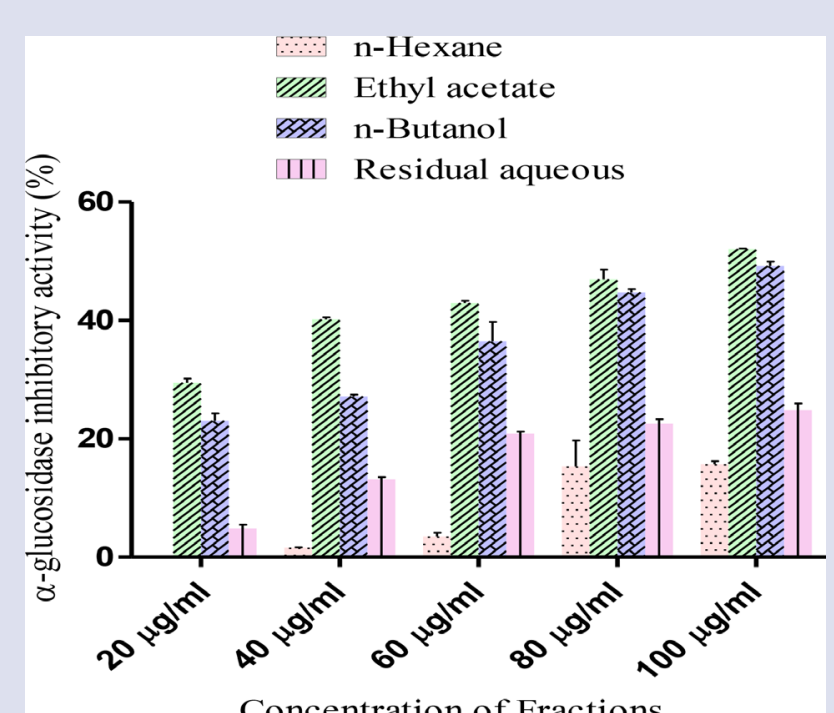

Concentration of Fractions

Figure 11: a-glucosidase inhibitory activities of various fractions from crude aqueous extracts of Bryophyllum pinnatum leaves.

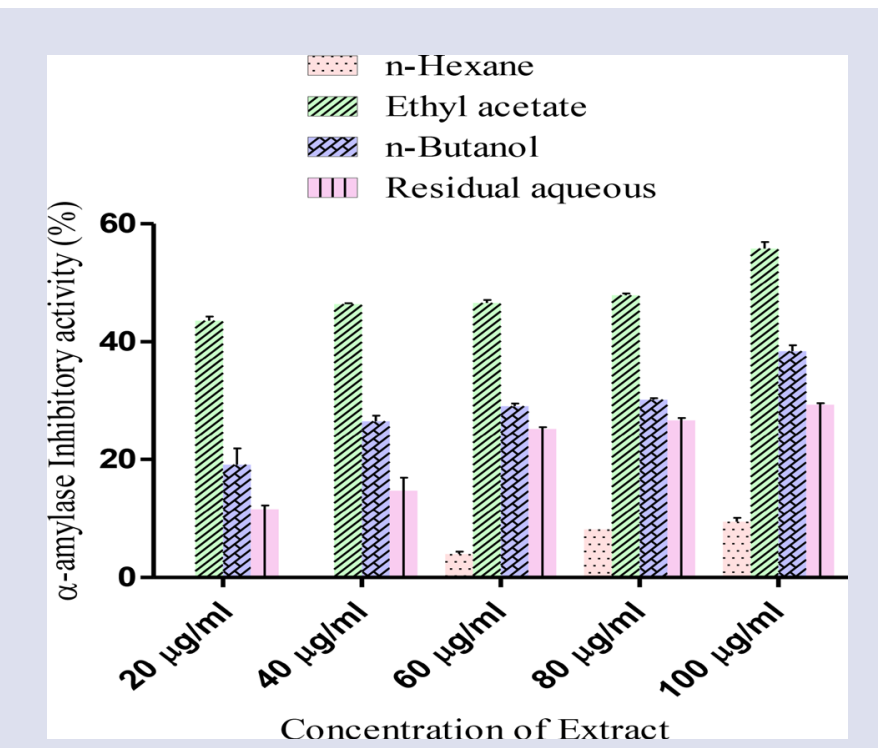

Figure 12: $a$-amylase inhibitory activities of various fractions from crude aqueous extracts of Bryophyllum pinnatum leaves.

by its ability to scale back $\mathrm{Fe}^{3+}$ to $\mathrm{Fe}^{2+}$. As displayed above, ethyl acetate fraction of $B$. pinnatum had higher reducing property of (3499.08 \pm $45.28 \mathrm{mg} \mathrm{AAE} / 100 \mathrm{~g}$ ) than the aqueous extract and all other fractions. Reducing properties is a defense system with two pathways obtainable to have an impact on this property are by e transfer and hydrogen transfer. ${ }^{14,30}$ The reducing capacity of the extracts could also be a sign of its potential antioxidant activities owing to the presence of reductants.

DPPH assays assess the power to scavenge radicals. The capacity to present a $\mathrm{H}$ atom may be a primary characteristic of antioxidants. These antioxidants present $\mathrm{H}$ atoms to free radicals, that converts the radicals into non-toxic species and so inhibits the propagation part of lipid oxidation. ${ }^{31}$ This study revealed that aqueous extracts (Figure 1) and various fractions from B. pinnatum leaves (Figure 7) scavenged radicals as the concentra-

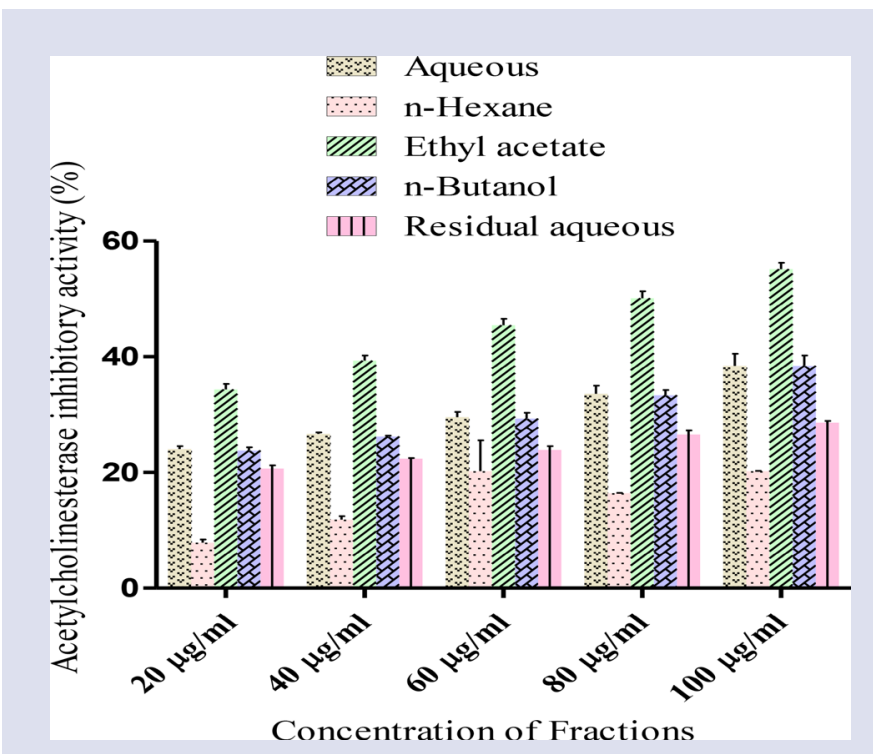

Figure 13: Acetylcholinesterase inhibitory activities of aqueous and various fractions from crude aqueous extracts of Bryophyllum pinnatum leaves.

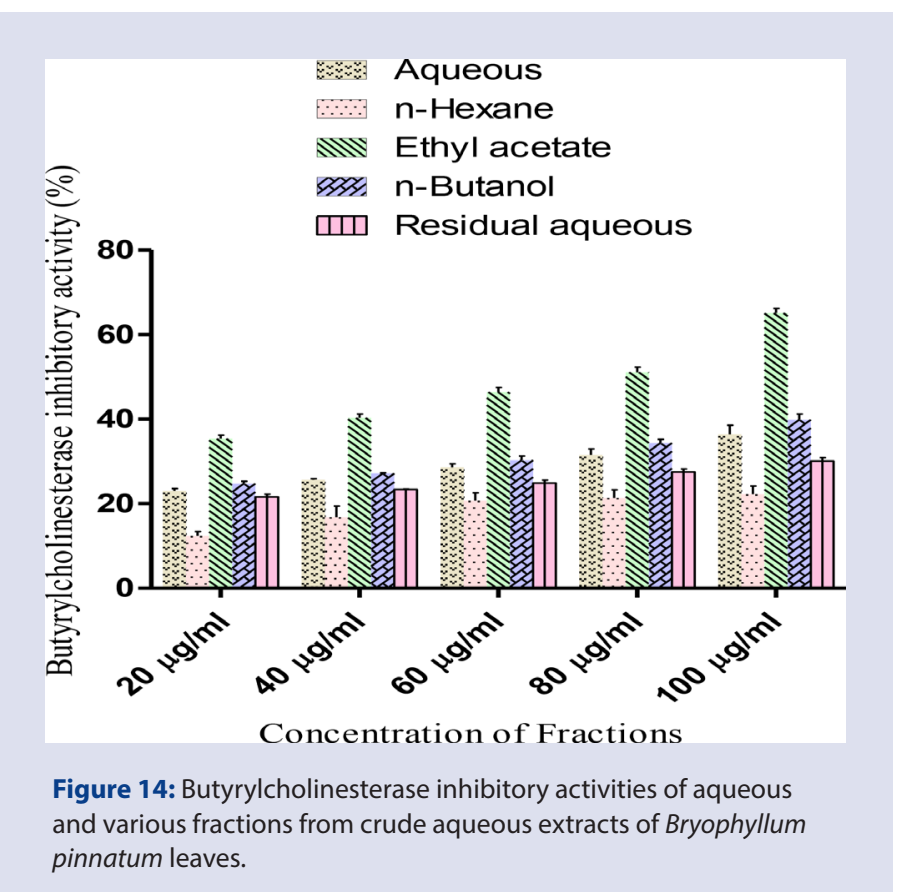

tion increases $\left(20-100 \mu \mathrm{g} \cdot \mathrm{mL}^{-1}\right)$. Though, radical scavenging abilities of the ethyl acetate fractions correlates with the total phenolic contents of the leaves. Thus, the observed DPPH radical scavenging ability can be attributed to the abundant phenolic constituents in the extracts and fractions. This is consistent with previous studies. ${ }^{29,32}$

Metal ion chelating ability is important since it reduces the concentration of the transition metal..$^{33}$ Hence, chelating $\mathrm{Fe}^{2+}$, generation of hydroxyl radicals in the Fenton reaction may be attenuated and thus prevent possible damage of hydroxyl radicals to biomolecules. Accumulation of iron has been reported to lead to an increase in free radicals and development of oxidative stress. ${ }^{34,35}$

The ability of water extract and various fractions of B. pinnatum on hydrogen peroxide radical is shown in Figure 3 and 9. B. pinnatum 
extracts and fractions were efficient in scavenging hydrogen peroxide radical. Though, ethyl acetate fraction of $B$. pinnatum leaves exhibited higher activity than the aqueous extract and all other fractions. Hydrogen peroxide may occasionally be lethal to cell and as a result give rise to hydroxyl radical within the cells though, it's not very reactive. ${ }^{36}$ Therefore, the eliminating of $\mathrm{H}_{2} \mathrm{O}_{2}$ is extremely vital for antioxidant defense. Rice-Evans. ${ }^{37}$ reported that compounds containing phenolic could play an important in eliminating radicals. The aqueous extract (Figure 4) and fractions (Figure 10) of B. pinnatum leaves might eagerly eliminate ABTS radical specifying the presence of secondary metabolites like flavonoids, phenolic (Table 1), that validate their action. However, ethyl acetate fraction of $B$. pinnatum leaf recorded the utmost quantity of radical reducing ability than the aqueous extract and all other fractions.

Enzyme assays have become an extremely valuable means to evaluate the potential health advantages of herbals, dietary supplements, and nutraceuticals for the development and design of functional foods or phytopharmaceuticals. ${ }^{38}$ Besides, most usual biochemical assays involve major enzymes applicable in metabolic syndrome like diabetes ( $\alpha$-amylase and a-glucosidase), and Alzheimer's disease (cholinesterases). ${ }^{39}$ This study reveals that the effects of the aqueous extract and various fractions of $B$. pinnatum leaves were further evaluated on several selected carbohydrate hydrolysis and cholinesterase assays, respectively, and the results are shown in Figure 5, 6, 11 and 12.

The inhibition of carbohydrate metabolizing enzymes like $a$-amylase and $\alpha$-glucosidase delays the digestion and absorption of starch and later suppresses postprandial symptom. $\alpha$ - amylase and $\alpha$-glucosidase inhibitory activities of $B$. pinnatum leaf extracts and fractions are shown in (Figure 5, 6, 11, 12) been helpful as oral antidiabetic drugs for the management of high blood sugar in patients with these syndromes. Inhibitions of these enzymes interrupt macromolecule digestion and overall extent the breakdown time inflicting a discount in the degree of glucose ingestion and thus plummeting postprandial blood sugar. ${ }^{40}$ However, aqueous extract and all the fractions of $B$. pinnatum leaf inhibited both $\alpha$ - amylase and $\alpha$-glucosidase. The highest percentage inhibition of the $\alpha$-amylase by the ethyl acetate fraction of $B$. pinnatum resulted in its low $\mathrm{IC}_{50}$ value $(62.45 \pm 1.22 \mu \mathrm{g} / \mathrm{mL})$ which implies that it is the most potent inhibitor of the enzyme out of the extracts and all the other fractions. This is consistent with earlier studies that antidiabetic agents derived from plants are strong inhibitors of a-glucosidase. ${ }^{41,42,43}$ This implies that ethyl acetate fractions of $B$. pinnatum leaf offer better pharmacological effect than the common synthetic drugs.

Enzyme inhibitors delivering antioxidant roles shows potential in instances of neurodegenerative diseases, because of their defensive role against radical species. ${ }^{44}$ In spite of issues regarding absorption, metabolism and precise mechanisms of action in vivo, the screening for cholinesterase inhibitors found in plants is valid in highlighting those compounds with the most promise of biological activity. ${ }^{45}$ Besides, cholinesterase inhibitors are still the best available option for managing patients suffering from Alzheimer's disease. Hence, the aqueous extract and various fractions of $B$. pinnatum was active against acetylcholinesterase, whilst ethyl acetate fractions of $B$. pinnatum presented highest inhibitory effect (Figure 13) than the aqueous extract and all other fractions. Furthermore, for butyrylcholinesterase, ethyl acetate fractions of B. pinnatum revealed a higher inhibitory activity than aqueous extract, n-hexane, n-butanol and residual aqueous fractions (Figure 14). Ethyl acetate fractions of B. pinnatum inhibit $\mathrm{AChE}$ and $\mathrm{BChE}$ activities as the concentration increases. This is in pact with some previous studies where plant secondary metabolites revealed a considerably enhancement in reasoning and reminiscence. ${ }^{46,47} \mathrm{AChE}$ and $\mathrm{BChE}$ inhibitory activity may be owing to the antioxidant properties of B. pinnatum.

\section{CONCLUSION}

This study discovered the phytochemical composition, antioxidant activity and enzyme inhibitory activities of $B$. pinnatum leaves. The extract and fractions of $B$. pinnatum scavenging radicals and had an inhibitory effect on enzymes associated to diabetes and Alzheimer's diseases in vitro. Furthermore, B. pinnatum presented a higher level of total phenolic and thus showed enhanced antioxidant and enzyme inhibitory effects. Additional studies are essential to clarify the mechanisms of in vivo antioxidant and enzyme inhibition action, bioavailability and concerned metabolic pathways.

\section{ACKNOWLEDGEMENT}

The Authors wish to acknowledge the Department of Biochemistry, Afe Babalola University for Providing the necessary facilities to carry out this study.

\section{CONFLICT OF INTEREST}

We declare that there are no conflicts of interest.

\section{ABBREVIATIONS USED}

ABTS: 2,2'-azino-bis(3-ethylbenzothiazoline)-6-sulphonic acid; AChE: acetylcholinesterase; AF: residual aqueous fraction; ATCI: acetylthiocholine iodide; BChE: butyrylcholinesterase; Bryophyllum pinnatum: B. pinnatum; BF: butanol fraction; BTCI: butyrylthiocholine chloride; g: gram; GAE: Gallic acid equivalents; DMSO: dimethylsulfoxide, (DMSO), DNS: dinitrosalicylic acid; DPPH: 1,1-diphenyl-2-picrylhydrazil; DTNB: 5,5-dithio-bis(2- nitrobenzoic) acid; EAF: ethyl acetate fraction; EDTA: ethylenediaminetetraacetic acid; HF: Hexane fraction; pNPG: p-nitrophenyl-a-D-glucopyranoside.

\section{REFERENCES}

1. Krishnaiah $D$, Sarbatly $R$, Nithyanandam $R$. A review of the antioxidant potential of medicinal plant species. Food Bioprod. Process. 2011;89(3):217-33. doi: 10.1016/j.fbp.2010.04.008

2. Shahidi F, Ambigaipalan P. Phenolics and polyphenolics in foods, beverages and spices: antioxidant activity and health effects-A review. J. Funct. Foods. 2015;18:820-97. doi: 10.1016/j.jff.2015.06.018.

3. Okwu DE, Josiah C. Evaluation of the chemical composition of two Nigerian medicinal plants. Afr. J. Biotechnol. 2006;5(4):357-61.

4. Sofowora A. Medicinal Plants and Traditional Medicine in Africa. Spectrum Books Ltd., Ibadan, Nigeria. 1982:191-289.

5. Ojewole JAO. Antihypertensive properties of Bryophyllum pinnatum (Clam) Oken leaf extracts. Am. J. Hypertension. 2002;15(s3):34-9.

6. Igwe SA, Akunyili DN. Analgesic Effects of Aqueous extracts of the leaves of B. Pinnatum. Pharmaceut Biol. 2005;43(8):658-61.

7. Afzal B, Hussain SMA, Basra HU, Rehman H. Priming with moringa leaf extract reduces imbibition chilling injury in spring maize Seed. Sci Technol. 2012;40(2):271-6.

8. YamagishiT, Haruna M, Yan YZ et al. Structure and Stereochemistry of bryophyllin-A, a novel cytotoxic bufadienolide orthoacetate from B. pinnatum. Chem. Bull. 1988;36(4): 1615-7.

9. Akinpelu DA. Anti-microbial activity of Bryophyllum pinnatum leaves. Fitoterapia. 2000;71(2):193-4

10. Llorent-Martínez EJ, Gouveia S, Castilho PC. Analysis of phenolic compounds in leaves from endemic trees from Madeira Island. A contribution to the chemotaxonomy of Laurisilva forest species. Ind. Crops Prod 2015;64:135-51. doi: 10.1016/j.indcrop.2014.10.068

11. Mocan A, Vodnar D, Vlase $L$ et al. Phytochemical Characterization of Veronica Officinalis L., V. teucrium L. and V. orchidea Crantz from Romania and Their Antioxidant and Antimicrobial Properties. Int. J. Mol. Sci 2015;16(9):21109-27. Doi: 10.3390/ijms160921109.

12. Vlase L, Mocan A, Hanganu D et al. Comparative study of polyphenolic content antioxidant and antimicrobial activity of four Galium species (Rubiaceae). Dig. J. Nanomater. Biostructures. 2014;9(3):1085-94.

13. Chan K, Shaw D, Simmonds MS et al. Good practice in reviewing and publishing studies on herbal medicine, with special emphasis on traditional Chinese medicine and Chinese materia medica. J. Ethnopharmacol. 2012;140(3):469-75. 
14. Ojo OA, Oloyede OI, Tugbobo OS et al. Antioxidant and inhibitory effect of scent leaf (Ocimum gratissimum) on $\mathrm{Fe}^{2+}$ and sodium nitroprusside induced lipid peroxidation in rat brain in vitro. Adv Biol Res. 2014;8(1):8-17.

15. Pulido R, Bravo L, Saura-Calixto F. Antioxidant activity of dietary polyphenols as determined by a modified ferric reducing/antioxidant power assay. J Agric. Food. Chem. 2000;48(8):396-402.

16. Puntel RL, Nogueira CW, Rocha JBT. Krebs cycle intermediates modulate Thiobarbituric Acid Reactive Species (TBARS) production in rat brain in vitro. Neurochem. Res. 2005; 30(2):225-35.

17. Gyamfi MA, Yonamine M, Aniya Y. Free-radical scavenging action of medicinal herbs from Ghana: Thonningia sanguinea on experimentally-induced liver injuries. Gen. Pharmacol. 1999;32(6):661-7.

18. Re R, Pellegrini N, Proteggente $A$, et al. Antioxidant activity applying an improved ABTS radical cation decolorization assay. Free Radic. Biol. Med. 1999;26(9):1231-37.

19. Ruch RJ, Cheng SJ, Klaunig JE. Prevention of cytotoxicity and inhibition of intracellular communication by antioxidant catechins isolated from Chinese green tea. Carcinogenesis. 1989;10(6):1003-8.

20. Shai LJ, Masoko P, Mokgotho MP et al. Yeast alpha glucosidase inhibitory and antioxidant activities of six medicinal plants collected in Phalaborwa, South Africa. South Afr. J. Bot. 2010;76(3):465-70

21. Ademiluyi $A$, Oboh G. Soybean phenolic-rich extracts inhibit key-enzymes linked to type 2 diabetes ( $\alpha$-amylase and $\alpha$-glucosidase) and hypertension (angiotensin I am converting enzyme) in vitro. Exp. Toxicol. Pathol. 2013;65(3):305-9.

22. Ellman GL, Courtney KD, Andres V. et al. A new and rapid colorimetric determination of acetylcholinesterase activity. Biochem Pharmacol. 1961;7(2):88-95.

23. Zar JH. Biostatistical analysis. Prentice-Hall Inc, Upper Saddle River, NJ, 1984.

24. R Core Team. R: A language and environment for statistical computing. R Foundation for Statistical Computing, Vienna, Austria, 2012. URL http://www.Rproject.org/.

25. Spanou C, Stagos D, Aligiannis N et al. Influence of potent antioxidant leguminosae family plant extracts on growth and antioxidant defense system of Hep2 cancer cell line. J. Med. Food. 2010;13(1):149-55. doi:10.1089/jmf.2009.0058.

26. Ojo OA, Oloyede Ol. Extracts of Ocimum gratissimum leaves inhibits $\mathrm{Fe}^{2+}$ and sodium nitroprusside induced oxidative stress in rat liver. Journal of Pharmaceutical and Scientific Innovations. 2016;5(3):85-89. DOI:10.7897/2277-4572.05318.

27. Hoensch HP Oertel $R$. The value of flavonoids for the human nutrition: Short review and perspectives. Clin. Nutr. Exp. 2015;3:8-14. doi:10.1016/j. yclnex.2015.09.001.

28. Pietta PG. Flavonoids as antioxidants. J. Nat. Prod. 2000;63(7):1035-42 doi:10.1021/np9904509.

29. Ojo OA, Oloyede OI, Olarewaju Ol et al. In vitro Antioxidant Activity and Estimation of Total Phenolic Content in Ethyl Acetate Extract of Ocimum gratissimum. PharmacologyOnline. 2013;3:37-44.

30. Dastmalchi K, Dorman HJD, Korsa M et al. Chemical composition of in vitro antioxidant evaluation of a water soluble mediavan balm (Dracocephalum moldavica L.) Extract. Lebensmittel-Wissenschaft Technol. 2007:40:239-48.

31. Ordoñez AAL, Gomez JD, Vattuone MA et al. Antioxidant activities of Sechium edule (Jacq.) Swartz extracts. Food Chem. 2006;97(3):452-8.

\section{GRAPHICAL ABSTRACT}

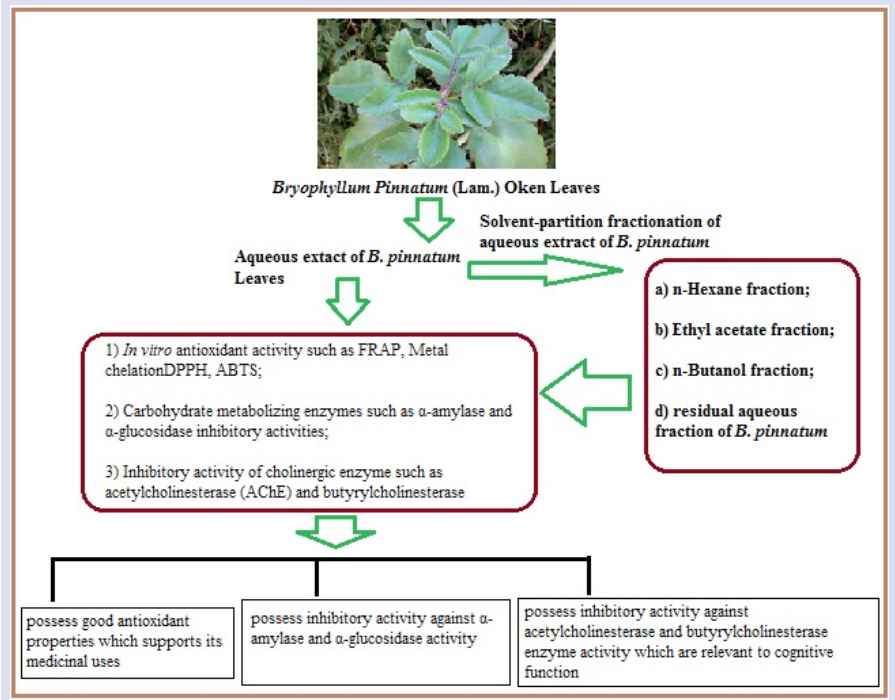

32. Tanaka M, Kuei CW, Nagashima $Y$ et al. Application of antioxidative maillrad reaction products from histidine and glucose to sardine products. Nippon Suisan Gakkaishi. 1998; 54:1409-14.

33. Duh PD, Tu YY, Yen GC. Antioxidant activity of water extract of Harng Jyur (Chrysenthemum morifolium Ramat). Lebnes. Wiss. Technol. 1999;32(5):269-77.

34. Ojo OA, Ojo AB. Inhibitory Activity of Tithonia diversifolia (Hemsl.) A. Gray leaves on Some Pro-Oxidant Induced Oxidative Stress in Rat Brain. Toxicol Int 2016;23(3):254-9.

35. Oyetayo FL, Ojo OA. Dennettia tripetala seeds inhibiting ferrous sulfate-induced oxidative stress in rat tissues in vitro. Oxidants. Antioxi. Med. Sci. 2017;6(2):35-9.

36. Halliwell B. Reactive oxygen species in living systems: Source, biochemistry, and role in human disease. American Journal of Medicine. 1991;91(3):14-22.

37. Rice-Evans CA, Miller NM, Paganda G. Structure-antioxidant activity relationships of flavonoids and phenolic acids. Free Radical Biology and Medicine. 1996;20(7):933-56.

38. Zengin G, Locatelli M, Carradori S et al. Total Phenolic, Flavonoids, Condensed Tannins Content of Eight Centaurea Species and Their Broad Inhibitory Activities against Cholinesterase, Tyrosinase, $\alpha$ - Amylase and $\alpha$-Glucosidase. Not Bot Horti Agrobo. 2016; 44(1):195-200

39. Bahadori MB, Valizadeh H, Asghari B et al. Chemical composition and antimicrobial cytotoxicity, antioxidant and enzyme inhibitory activities of Salvia spinosa L. J. Funct. Foods. 2015;18:727-36.

40. Ojo OA, Ajiboye BO, Olayide I et al. Ethyl acetate fraction of bark of Bridelia ferruginea Benth. Inhibits carbohydrate hydrolyzing enzymes associated with type 2 diabetes ( $\alpha$-glucosidase and $\alpha$-amylase). Advances in Bioresearch. 2016;7(3):126-33. DOI: 10.15515/abr.0976-4585.7.3.126133.

41. Ojo OA, Ojo AB, Ajiboye BO et al. Helianthus annuus Leaf Ameliorates Postprandial Hyperglycaemia by inhibiting carbohydrate hydrolyzing enzymes as sociated with Type-2 diabetes. Iranian Journal of Toxicology. 2016;10(5):17-22.

42. Kazeem MI, Ogungbe SM, Saibu GM et al. In vitro study on the hypoglycemic potential of Nicotiana tabacum leaf extracts. Bangladesh J Pharmacol. 2014;9(2):140-5

43. Ajiboye BO, Ojo OA, Adeyonu O et al. Inhibitory effect of key enzymes relevant to acute type-2-diabetes and antioxidative activity of ethanolic extract of Artocarpus heterophyllus stem bark. Journal of acute disease. 2016;5(5):423-9.

44. Sarikurkcu C, Tepe B. Biological activity and phytochemistry of firethorn (Pyracantha coccinea M.J. Roemer). J. Funct. Foods. 2015;19:669-75.

45. Roseiro LB, Rauter AP, Serralheiro MLM. Polyphenols as acetylcholinesterase inhibitors: Structural specificity and impact on human disease. Nutr. Aging 2012;1(2):99-111. Doi: 10.3233/NUA-2012-0006.

46. Adefegha SA, Oboh G. Acetylcholinesterase (AChE) inhibitory activity, antioxidant properties and phenolic composition of two Aframomum species. J. Basic Clin. Physiol. Pharmacol. 2012;23(4):153-61.

47. Ojo OA, Oyinloye BE, Ajiboye $\mathrm{BO}$ et al. Dichlorvos induced oxidative stress in rat brain: Protective effects of Ethanolic extract of Alstonia boonei stem bark Asian J. Pharm. 2014c: 8(4):216-21.

\section{SUMMARY}

That Bryophyllum pinnatum leaves extract possess strong anti-diabetes and anti-Alzheimer's activity via

- possess good antioxidant properties which supports its medicinal uses;

- possess inhibitory activity against $\alpha$-amylase and $\alpha$-glucosidase activity;

- possess inhibitory activity against acetylcholinesterase and butyrylcholinesterase enzyme activity which are relevant to cognitive function.

\section{ABOUT AUTHORS}

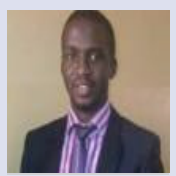

Oluwafemi Adeleke Ojo: is an academic researcher at Afe Babalola University, Ado-Ekiti, Nigeria. He has published more than 30 peer review research articles, and 10 conference proceedings. The author's work has been published in Phytomedicine, Medical, Pharmacology and Pharmacognosy journals. His research work is focused on the Anti-Diabetic Potentials and Associated Molecular Mechanism of Bioactive Compounds in African Medicinal Plants. He has projects in collaboration with interna $\neg$ tional institutions. 


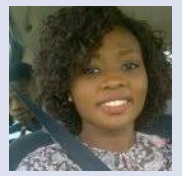

Adebola Busola Ojo, a Doctoral Candidate at Department of Biochemistry, Faculty of Science, Ekiti State University, Ado-Ekiti, Nigeria. She is a lecturer at Department of Medical Biochemistry, College of Medicine and Health Sciences, Afe Babalola University, Ado-Ekiti, Nigeria. The doctoral research focused on the isolation, identification, characterization of antidiabetic bioactive principles of flavonoids-rich extract.

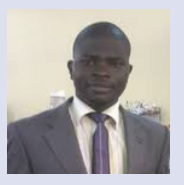

Basiru Olaitan Ajiboye, Ph.D., is a Senior Lecturer and Co-coordinator of Biochemistry program in the Department of Chemical Sciences, Afe Babalola University, Nigeria. His research interest is on plant based diet in managing related metabolic disorders. Has experience in the area of Phytomedicine, Nutraceuticals and Nutritional Biochemistry.

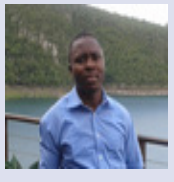

Babatunji Emmanuel Oyinloye, Ph.D., is a Lecturer of Biochemistry and postgraduate coordinator, at Afe Babalola University, Ado-Ekiti, Nigeria. His research focus is on structural Biology and Biotechnology with interest in Infectious Diseas $\neg$ es. Has experience in the area of Phytomedicine, Bioinformatics, Structural Biology and Biotechnology.

Cite this article: Ojo OA, Ojo AB, Ajiboye BO, Olaiya O, Akawa A, Olaoye O, Anifowose OO, Idowu O, Olasehinde O, Obafemi T, Awe $\mathrm{J}$, Oyinloye BE. Inhibitory effect of Bryophyllum pinnatum (Lam.) Oken leaf extract and their fractions on a-amylase, a-glucosidase and cholinesterase enzyme. Pharmacog J. 2018;10(3):497-506. 